\title{
ANAIS DA \\ ESCOLA SUPERIOR DE AGRICULTURA \\ "LUIZ DE QUEIROZ"
}

\begin{abstract}
Saem agora, pela primeira vez, os ANAIS DA ESCOLA SUPERIOR DE AGRICULTURA “LUIZ DE QUEIROZ”, da Universidade de São Paulo. Com essa publicação, cuja necessidade já se fazia sentir, pretende a Escola de Piracicaba reunir os trabalhos de seus professores e assistentes, que até aqui vinham saindo esparsos em revistas nacionais e estrangeiras, algumas das quais pouco acessíveis aos nossos agrônomos, que dêsse modo se viam impossibilitados de acompanhar o desenvolvimento científfico, hoje considerável, de uma das maiores e mais bem aparelhadas escolas de agronomia do continente americano. Também visou a Escola, com a publicação de seus ANAIS, incentivar a pesquisa, pondo à disposição de todos quantos trabalham e estudam, um órgão idôneo, que por meio de suas separatas dará imediata divulgação no país e no exterior, ao resultado das investigações realizadas, garantindo, assim, prontamente, para os respectivos autores, a prioridade das idéias, teorias e fatos novos apresentados.

Os ANAIS correspondentes a cada ano serão distribuidos no inicio do ano seguinte. As separatas dor artigos terão, porém, imediata distribuição.

Os ANAIS destinam-se a distribuição apenas às Bibliotecas, Institutos e Instituições técnicas e científicas, enquanto as separatas serão enviadas aos técnicos e cientistas que, pela natureza de sua especialização, se interessem pelo assunto publicado.
\end{abstract}




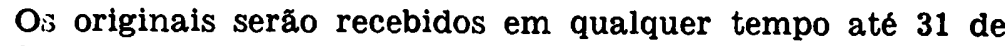
outubro. Após essa data a Comissão Redatora não assumirá o compromisso de publicação dos trabalhos apresentados, senão nos Anais do ano seguinte.

A ordem de publicação será o da entrega dos originais ao secretário da Comissão Redatora, que é o Bibliotecário da Escola, c qual dará o competente recibo.

A juizo da Comissão Redatora, trabalhos que pela sua natureeza dificultarem a composiçăo, atrazando a publicaçăo de outros mais simples, por conterem tabelas, fórmulas e gráficos complicados, poderão ceder seu lugar a êstes, mesmo que tenham sido recebidos com alguma antecedência.

Os trabalhos dos assistentes deverão trazer o "visto" dos respectivos chefes.

A ortografia adotada será, tanto quanto possivel, a que se cncontra no "Pequeno vocabulário ortográfico da língua portuguesa" publicado pela Academia Brasileira de Letras e no "Vocabulário" da Academia das Ciências de Lisboa. Os têrmos não constantes dêsses vocabulários serão grafados de conformidade com as regras nêles adotadas.

A Comissão Redatora estará sempre à disposiçăo dos autores para entendimentos relativos à publicação de seus trabalhos.

A cada autor será fornecida uma segunda prova de seu artigo, jà paginada e corrigida, que deverá ser devolvida à Redação dentro do prazo de 48 horas. Findo êsse prazo, a Comissão Redatora corrigirá uma segunda via da mesma e a fará imprimir sem dar mais vistas ao autor. Acréscimos e supressóes de trechos só serão admitidos se não prejudicarem a paginação, pelo que os autores deverão rever cuidadosamente os originais antes de entregá-los.

Pelo fato da Comissão dos Anais só ter sido nomeada quando o presente volume se achava quase concluido, inúmeras incorreções serão nêle notadas, as quais esperamos, serăo sanadas no futuro. cada a

A correspondéncia destinada aos ANAIS deverá ser endere-

Anais da Escola Superior de Agricultura "Luiz de Queiroz"

Biblioteca

PIRACICABA, Estado de São Paulo, BRASIL 